African Crop Science Journal by African Crop Science Society is licensed under a Creative Commons Attribution 3.0 Uganda License. Based on a work at www.ajol.info/ and www.bioline.org.br/cs DOI: https://dx.doi.org/10.4314/acsj.v28i4.5

\title{
ANALYSIS OF STAKEHOLDER PERCEPTIONS AND PRACTICES RELATED TO CLIMATE CHANGE ADAPTATION IN BURKINA FASO
}

\author{
Z.N. GAHI ${ }^{1,2}$, M.K.A. KABLAN ${ }^{1,3}$, O.J.G. KPAN ${ }^{4}$, K. DONGO ${ }^{1,3}$ and M. BADOLO ${ }^{2}$
}

${ }^{1}$ Université Felix Houphouet-Boigny (UFHB), Abidjan, Côte d'Ivoire ${ }^{2}$ Centre Africain de Recherche Scientifique et de Formation (CRES), Ouagadougou, Burkina Faso

${ }^{3}$ Centre Suisse de Recherches Scientifiques en Côte d'Ivoire (CSRS)

${ }^{4}$ Université Paléforo Gon Coulibaly, Korhogo (UPGC), Côte d'Ivoire

Corresponding author: gahi_z@yahoo.fr, gahizn@gmail.com

(Received 10 September 2020; accepted 6 November 2020)

\begin{abstract}
Burkina Faso, like other Sahelian countries, has experienced a profound change in its climatic regime, with the new context characterised by high rainfall variability with an overall downward trend and a shortening of the seasons. The future rainfall pattern anticipates a decrease in the frequency of low rainfall ( 0.1 to $5 \mathrm{~mm}$ per day), a lengthening of the average duration of dry sequences, and an early end and late start of rainy seasons. The objective of this study was to perform an in-depth analysis of stakeholder perceptions about agricultural water (AgWater) resources sustainability, practices in the context of climate variability and change in Burkina Faso. Interviews were held with institutional actors involved in water resources decision making and initiatives (Government, Research, NonGovernmental Organisations) in the country. In addition, based on four main criteria (climate condition, type of farm and crop, type of AgWater sources, reliability of AgWater), three agricultural sites were investigated using household surveys. The results showed that organisations and farmers in Burkina Faso were aware of climate impacts and had initiated and implemented for many years, diverse options and water control mechanisms for AgWater adaptation. However, there were still gaps in strategies for adapting the water sector to climate threats. Institutional bodies had not got yet attained capacity to sustainably anticipate the effects of climate change on AgWater. There was a lack of mainstreaming hydroclimate services at farm levels, especially for the dry season crops; lack of on-farm flood control mechanisms, absence of a clear gender approach and no standardised monitoring system, Farmers also lacked anticipatory resilience strategies, particularly those who used water sources that were considered as "reliable" then. In general, most of the climate adaptation initiatives implemented lacked synergies, sustainability, and were uncertain about sound water resource management such as moving towards "no regret" and "win-win" options.
\end{abstract}

Key Words: Agricultural water, hydroclimate services, resilience strategies 
Le Burkina Faso, à l'instar des pays du Sahel, a connu un changement considérable de son régime climatique. Le nouveau contexte climatique est caractérisé par une forte variabilité et une baisse de la fréquence des précipitations ( 0,1 à $5 \mathrm{~mm}$ par jour), un allongement de la durée moyenne des séquences sèches, une fin précoce et un début tardif des saisons des pluies. L'objectif de cette étude était donc d'effectuer une analyse approfondie des perceptions et pratiques des acteurs au regard de la sécurité en eau agricole dans un contexte de changement climatique au Burkina Faso. Des entretiens semistructurés ont été conduits avec les acteurs institutionnels impliqués dans la gestion de l'eau agricole (décideurs, chercheurs, praticiens). Aussi, sur la base de quatre critères principaux (conditions climatiques, type d'exploitation et de cultures, type de sources d'eau agricole, fiabilité de la source d'eau), trois sites agricoles ont été sélectionnés et des enquêtes conduites auprès des agriculteurs. Les résultats ont montré que l'ensemble des acteurs institutionnels ou usagers expérimentent les effets du climat sur l'eau agricole. En outre, de nombreuses initiatives et mécanismes, qui contribuent à l'adaptation de cette ressource, ont été mis en œuvre depuis de nombreuses années. Toutefois, il existe encore de nombreuses lacunes dans les stratégies pour une adaptation durable de l'eau agricole aux menaces climatiques. Les acteurs institutionnels n'ont pas encore la capacité d'anticiper efficacement les effets des changements climatiques. Il n'existe pas encore de services hydroclimatiques au niveau des exploitations agricoles, notamment pour les cultures de saison sèche ; de même que l'absence de mécanismes de maitrise des inondations sur ces exploitations agricoles, la promotion d'une approche genre spécifique et le manque d'un système standard de suivi de la résilience. Les agriculteurs manquent de stratégies anticipatives d'adaptation, en particulier autour des sources d'eau considérées comme "fiables". En général, la plupart des initiatives actuelles d'adaptation au climat manquent de synergies, et la prise en compte de l'incertitude climatique comme l'orientation vers les " options sans "regret" ou "gagnant-gagnant".

Mots Clés : Eau agricole, services hydroclimatiques, stratégies de résilience

\section{INTRODUCTION}

It is widely predicted that Africa will largely bear the burden of climate change impacts in future yet the continent seems to be less prepared for the risks (warning, responses) and damage (building back) (Schaeffer et al., 2012). Since 1970s, Burkina Faso, like other Sahelian countries, has experienced a profound change in its climatic regime ( Taylor et al., 2009a; 2009b; Ibrahim et al., 2014). The new climatic context is characterised by high rainfall variability with an overall downward trend; and a shortening of the seasons (Karambiri and Garc, 2011). The future rainfall pattern anticipates a decrease in the frequency of low rainfall ( 0.1 to $5 \mathrm{~mm}$ per day), a lengthening of the average duration of dry sequences and an early end and late start of rainy seasons (Ibrahim et al., 2014; Kabore et al., 2015).
However, these authors reported a slight increase in the occurrence of extreme rainy days. Moreover, hot periods are lengthening as opposed to cold periods, which are decreasing.

The effects of climate change are also perceptible through the early drying up of most rivers and small dams. Schmengler (2011) mentioned $15 \%$ loss of storage capacity and $60 \%$ drop in critical water levels in reservoirs and small dams, such as those in the Southwest of Burkina Faso over the last 20 years. Filippi et al. (1990) noted a continuous decrease in groundwater recharge in the Massili in Borogo and Silmissin, both in Burkina Faso; leading to a 1 to $1.9 \mathrm{~m}$ drop in the water table since 1980; and an average decrease in groundwater levels of 1 to $3 \mathrm{~m}$ nationally (Mouhouyouddine et al., 2017). Gahi et al. (2019), they noted an early drying of community wells (up to $13 \mathrm{~m}$ 
in depth); while Sossou et al. (2019) highlighted the impacts of climate drivers on crop yield. According to these authors, within a short term, an increase in temperatures of $1^{\circ} \mathrm{C}$ would result in a decrease in cereal yield of $72 \mathrm{~kg}$ per hectare; while in the long-term period, a rise in temperatures of $1^{\circ} \mathrm{C}$ would result in a decrease in cereal yield of $1074 \mathrm{~kg}$ per hectare.

In the last decade, drought and flood events have sequentially worsened in Burkina Faso. Both droughts and floods have severely impacted water security, with consequential negative impacts on agricultural production (Gahi et al., 2015; 2017). In fact, these impacts on water resources imply disruption in agricultural activities, early drying of wells and rivers, loss of soil humidity and fertility, loss of seasonal crop and vegetable productivity. These can result in food insecurity if timely alternative interventions to buffer such disasters are not implemented (Gahi et al., 2017). These studies also noted that, although there was integrated water resource management and food insecurity plans to face to food crises in Burkina Faso, water insecurity was still experienced by farmers; followed drought or flood events. Sustainable management of climate impacts involves putting in place well adapted policies and then strategies for enhancing water availability and access. However, making policy by decision makers and putting into practices and use these strategies mainly at the community level requires understanding of the strategies as perceived by end-users. Therefore, the objective of this study was to perform an indepth analysis of stakeholder perceptions about agricultural water (AgWater) resources sustainability and their practices in the context of climate variability and change in Burkina Faso.

\section{MATERIALS AND METHODS}

The study area. This study was conducted in Burkina Faso in west Africa. Burkina Faso is a Sahelian country, with $84 \%$ of the population economy and livelihoods based on the agricultural sector. According to a recent study about water resources assessment and management framework (MEE, 2001), agriculture alone accounts for more than $64 \%$ of the total water consumer demand. The irrigable areas are estimated at 233,500 ha, and only $14 \%$ was effectively explored (Evans $e t$ al, 2012).

Burkina Faso is characterised by an average annual rainfall ranging from $300 \mathrm{~mm}$ in the north, to $1200 \mathrm{~mm}$ in the south-west; with a very high temporal variability (Ibrahim et al., 2014). The country is subdivided into three main climatic zones, namely the Sahelian zone in the northern part, with an average annual rainfall of 300 to $600 \mathrm{~mm}$; the SudanSahelian zone (600-900 $\mathrm{mm}$ per year) in the centre; and the Sudanian zone (900-1200 mm per year) in the south. Rainfall has a tropical dry and unimodal regime, characterised by two seasons, a short rainy season of four to five months (May/June to September) and a long dry season varying from seven to eight months on average.

Evapotranspiration amounts to more than $2000 \mathrm{~mm}$ per year, representing $80 \%$ of total rainfall. Winds are dominated by monsoon (bringing rain) and harmattan (hot dry season winds). Daily temperatures vary between 10 $16{ }^{\circ} \mathrm{C}$ for the minima (December-January) during Harmattan; and between $38-45^{\circ} \mathrm{C}$ for the maxima (March-May). Relative humidity goes from $20 \%$ in the dry season in the north, to $80 \%$ in the south, showing a high-water scarcity.

Recent decade droughts, floods and heats have severely impacted the country's farmer livelihoods, especially water resources Gahi $e t$ al., (2017). These different impacts of climate risks on hydrosystems have had adverse repercussions on livelihoods of communities that depend mainly on agriculture (Barbier and Yacouba, 2009; Zorom et al., 2013; Sossou et al., 2019). Gahi et al. (2015) identified vulnerability factors for agricultural water, which significantly lead to decrease of crop production and food insecurity. According to 
Gahi et al. (2015), the main inherent vulnerability factors include deficits in integrating climate risks in designing and running of the water managerial frameworks for crop production, lack of climate social policy and mechanisms (e.g. climate assurance mechanisms), gaps in climate information and in early warning system, deficits in mainstreaming climate risks into the design and management of the water sources.

Data collection. Three agricultural sites were selected for the household survey on perceptions and practices of urban farmers including uptake factors concerning resilience strategies. Site selection was guided by four criteria. The first criterion related to climate in order to better grasp the perceptions according to climatic zones. Thus, two sites were identified, namely in the Sudanian zone (Bobo-Dioulasso), and two in the SudanoSahelian zone (Ouagadougou).

The second criterion included the type of farm and crop, e.g. small market gardening. Indeed, small farms (05-1 ha) constituted most of the farming systems in Burkina Faso. The third criterion related to the type of primary water source exploited for irrigation, i.e. dams on the one hand and rivers only on the other. The fourth criterion considered the reliability (sustainability or not) of agricultural water on the sites. Indeed, at Bobo-Dioulasso, a river runs all year round; therefore, it is considered as a perennial source (Gahi et al., 2015).

Dams are the main sources of agricultural water at Tanguin and Boulimiougou; and are therefore, considered as ephemeral sources. At the Tanguin site, when the water level of the dam (which is firstly intended to supply drinking water to the population of the Ouagadougou city) drops drastically, it severely limits its access to urban farmers. However, the Boulimiougou dam is a source of water intended for agricultural activities, alternating with wells. The "garden" sites at Bobo-Dioulasso (in the Sudanian zone), and at Tanguin and Boulimiougou (in the SudanSahelian zone) were identified. In Bobo-
Dioualsso, the selected "market garden" was crossed by a perennial river call "BoboJardin", which served as a unique source of water for market gardening in the location.

The survey was conducted using a questionnaire. The survey together with data analysis, were based on the 24 vulnerability factors of the water sector identified by Gahi et al. (2017) in Burkina Faso. These vulnerability factors included the three main climatic indicators for agriculture risks (droughts, floods and temperature) considering climatic uncertainties in Burkina Faso.

The questionnaire survey considered only households who practiced the farming activity for at least ten years, in order to better consider the impacts of the successive climatic risks experienced over the last decade in the different locations. A random interview of 75 farming households, i.e. 25 per market gardening site out of an average of 200 households per site, was conducted. The main questions related to the key climatic risks experienced at the site, the adaptation strategies, the effectiveness of these strategies, the factors allowing them to use these strategies; and suggestions to improve access to water at the location, effectiveness of the development project in water vulnerability reduction in terms of sustainability.

Key informant interview involved 20 water decision makers and planners (national level $=7$, regional $=2$ ), agricultural extension service agents (4) and practitioners (NGOs, local associations =7 ), among those involving in agricultural water management in Burkina Faso. Actors were consulted independently to avoid inter-stakeholder influence and associated biases.

Data analysis. Several tools and methods were used to process and analyse the data collected. Content analysis, combined with the triangulation method, were used to analyse the interview data. The first (content analysis) consisted of an objective, exhaustive, methodical and quantitative review of all the 
information from the interviews in order to extract what is significant in relation to the research objectives (Gahi et al., 2015). Here, the terms related to perceptions, and practices of stakeholders were highlighted to better understand farmers' perceptions and practices with regard to climate change. Thus, the responses were codified in order to better perceive and structure the most frequently cited themes. The information received was classified either as perception or practices, then summarised according to the frequency terms; and then analysed with regard to the relevance to manage climate impacts. The second triangulation was used to integrate and cross-reference data from the surveys (semistructured interviews), field observations and literature in a single analysis. According to Carter et al. (2014), triangulation techniques were considered relevant to reduce bias through the convergence of information from different sources, and to develop a comprehensive understanding of an issue.

Using Tanagra 4.5 software, the descriptive statistics (percentage) were used to analyse response from market gardeners. A strength and weakness analysis were carried out using the SWOT (Strengths, Weaknesses, Opportunities and Threats) approach to highlight the cons and pros of agricultural water management projects in Burkina Faso. Nagara et al. (2015) intimated that the SWOT analysis is particularly useful as it allows a holistic qualitative approach to simplifying the multidimensional and interdisciplinary aspects of water management issues.

\section{RESULTS AND DISCUSSION}

Institutional actors' knowledge and practices. The institutions involved in mitigating climate effects on agricultural water Burkina Faso are presented in Table 1. Evidently, Burkina Faso has implemented, diverse options and water control mechanisms for agricultural production. The institutions were aware of climate impacts on agricultural water overall; and its implication for food insecurity. In fact, all interviewees mentioned reduced rainfall, frequent events of droughts, floods; and heat and how they can jeopardise rivers, dams, wells and then lead to lost crop production. However, the impacts of climate on water resources (early drying up of small dams, community wells and rivers), and rainfall instability (e.g. late start, early cessation), still hamper agricultural productivity (Hesse et al., 2013), and imply a deficit in strategies for adapting the water sector to climate threats. These show that implementing water resources plans and strategies are still weak in the country. Different institutional bodies, particularly the public institutions, do not seem to have the capacity to effectively anticipate and manage the effects of climate on water resources and associated socio-economic impacts. These included Ministry in charge of Water Resources, General Directorate for Water Resources (DGRE), the Permanent Secretariat for Integrated Water Resources Management (SP-GIRE), Water agencies local committees of water.

There has been noticed a decreasing trend of water availability for agricultural production in Burkina Faso, which has resulted in loss of crops, thus contributing to food insecurity; as also raised by Gorbeogo (2017) and NANA (2019) . This undoubtedly indicates that the combined effects of these different institutional mechanisms and arrangements are still far from meeting sustainable resilience requirements. Moreover, there is still little effective participation of all the institutional actors and users in the implementation of these initiatives, particularly in relation with implementation of Integrated Water Resources Management (IWRM) plan. This could be due to the gaps in institutional collaboration mechanisms and insufficient mainstreaming of water productivity in water policies.

There are significant deficits in knowledge and access to information on water management in relation to reducing climate risks in Burkina Faso. According to the institutional actors $(65 \%)$, one of the main 
TABLE 1. Organisations involved in agricultural water management in Burkina Faso following their areas of interest

Areas of interest /rôle Example of organisations

National water resources regulation and governance

Water resources monitoring

Ministry of water, Direction General des Ressources en Eau (DGRE)

Direction des Etudes et de l'Information sur l'Eau (DGRE/DEIE)

Water resources policy planning and implementation

SP/GIRE (Secretariat Permanent de la Gestion Integrée des Resources en Eau

Watershed level (Basin Water Agencies)

Agence de Nakanbé, Agence du Mouhoun, Agence de l'eau des Cascades, Agence de l'eau du Likpato, Agence de l'eau du Gourma,

Transboundary water regulation (Volta Basin)

Volta Basin Authority

Local level

Weather/climate information

Land use monitoring

Agricultural Water Technical implementation

Research

Local committees of water

Meteorological Office

Secrétariat Permanent du Conseil National pour l'Environnent et le Développement (SP/CONEDDDCIME)

INGOs (eg. Christian Aid, ), local development association,

Research and Academic institute and universities of Ougadougou, Institut International de l'Eau et de l'Environnement, Centre de Coopération Internationale en Recherche Agronomique pour le Développemen (CIRAD) 
deficits comes from the slowness in the effective implementation of technical actions and mechanisms prescribed in the regulatory frameworks and strategies.

Although water financing mechanisms were already in place, which included parafiscal fees for the benefit of water agencies concerning abstraction of water; and water pollution tax (Law 058/2009/AN of 15 December 2009); up to $55.4 \%$ of the respondents highlighted the preponderance of external financing in National Programme for IWRM (2016-2030). This clearly shows weaknesses of these current financing mechanisms.

Adaptation strategies and policies for water sector were dominated by significant inadequacies in the integration of climate change in the integrated water management programme. This might be due to lack of the anticipative vision and lack of climate uncertainty management strategies. This lack of anticipation accentuates both the exposure and sensitivity of this resource to extremes events; and consequently, its vulnerability and socioeconomic activities that depend on it (eg. Agriculture). This may be due to the weakness of the use scientific information, but also insufficiency of national climate funds.. Also, the lack of a formal functional interfaces between research, civil society, private sector and the political arena relating to water and disaster management, could explain the gaps in internalisation of climate information by the actors. Despite the existence of a national framework for the exchange and sharing of knowledge on water security, led by Water Aid (West Africa Regional Learning Center), in practice, the adoption of this framework by the other actors as a national water coordination instrument is still questionable. This framework is still perceived by others actors as the property of Water Aid, an international NGO working on water resources in Burkina Faso and other climate change affected countries in sub-Saharan Africa.

Institutional actors still face enormous difficulties in managing water resources, with pronounced deficits in flood management strategies at the plot. Yet in Burkina Faso, the current climate risks and their effects seem to be well known by the actors. More than 90\% of institutional actors interviewed cited droughts, floods and the reduction in number of rainy days as causes of the drop in crop production. Similarly, more than half $(55 \%)$ of the interviewees had a significant knowledge of some of the identified vulnerability factors revealed by this study. In addition, no hydrological-based information was provided by the hydrological services to the gardeners even the irrigation infrastructure such as dams, rivers or wells were mostly used for irrigation. This revealed that water management institutions and singularly National Directory of Water Resources via DEIE (Direction of Water Resources Monitoring and Studies) should reinforce their capacity and promote such services.

At the regional level, institutions such as ECOWAS (Economic Community of West African States), through its Water Resources Coordination Centre (CCRE) and Volta Basin Authority (63\% of the territory) still had insufficient capacity (technical, financial) for effectively integrating climate change considerations in their policies and strategies. There was no formal integrated climate adaptation policy in the region; and where such policy existed, there was no clear progress monitoring system like a MRV (Measurement, Reporting, and Verification) system in the agriculture sector. In addition, there is lack of technical resources human resources in the region to man climate change related intervention initiatives. As a result of this, there is a clear lack of a design of climate smart technology, insufficient knowledge of climate modelling, determination of specific emission factor, and pursuance of verification exercises. Furthermore, climate resilience related policies lacked integration of gender issues into water resources programme. This is the case of the ongoing National Programme for Integrated Water Resources Management (2016-2019), which do not advise if the 
planers or practitioners should go toward gender-response or gender-transformative approach to benefit from water resilience strategies the most.

Knowledge and practices of farmers. Farmers were aware of climate change impacts on agricultural water at plot level. Figure 1 (Cf. Illustration) shows some of the adaptation techniques implemented on the agricultural sites visited. In recent years, even if they are still marginal, techniques of crop association and agroforestry and climate information have been developed. From the interview, for many years, farmers in Burkina Faso have developed farmer-level adoption of soil and water techniques (CES/DES) to climate change. The best known of these techniques included planting pits, the Zaî, stone lines", "half-moon". CES/DES have been documented in the climate literature (Sidibe, 2005; Nyamekye et al., 2018). The CES/DES techniques are similar with those identified by Boansi et al. (2017), Sanfo et al. (2017) and, Faso and Callo-concha (2018) in Sudan Savanana in West Africa.

Results revealed that certain water resource users' strategies are not always initiated with the specific objective of water resource resilience to climate change. They are more often guided by an increase in agricultural productivity, although they may help address the effects of climate on water in certain manner. For instance, the study sites included the use of improved seeds that were more resistant to drought $(86 \%)$; and the use of organic manure (increasing water retention capacity of the soil and improving soil fertility). Although mineral fertilisers improved farmers' yields, their uncontrolled use ( $88 \%$ of them), would in the long run, hamper the quality of water resources and sound soil fertility management. Some farmers benefited from subsidies of agricultural inputs, such as mineral fertilisers, in this Sahelian region, where soils are predominantly nutrient-poor. However, fertiliser use ought to be supported by technical support that takes into account the reduction of long-term negative effects of these chemical to the ecosystem.

Some water use practices identified $(60 \%$ of respondents) in the surveyed locations used of motorised water pumps with capacity to regulate water use during irrigation. Unfortunately, the agricultural water resource users were unfamiliar with best water use

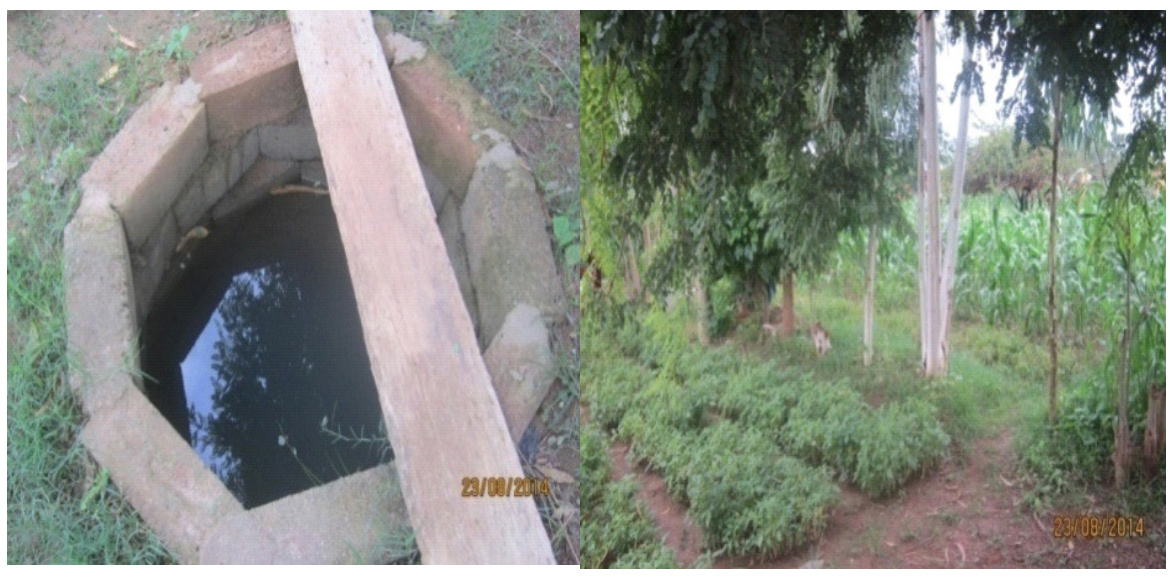

b

Figure 1. Some farmers' water management practices on the plot: (a) Protection against silting of the well (raising of the structure), (b) Crop association + agroforestry - ( maize, tomatoes, tree) in Boulimiougou. 
practices for agricultural and other household water demands. This led to abusive and uncontrolled use of water resource in the country.

Most farmers irrigated their crops twice a day, especially in the mornings and afternoons. These practices likely amplified the waste of agricultural water since evaporation was quite high $(80 \%$ on average) in this region (MEE, 2001). Farmers need adequate technical advisory support on climate smart agricultural practices. Indeed, only less than $20 \%$ of users reported having received technical advice on efficient agricultural water management from extension service provides. In the vegetable site visited, though farmers were aware of climate change impacts on unreliable availability of water and hear about climate information, no formal climate service were provided. In addition, climate services related hydrological-based information should make sense for them as vegetable activities take place at the end of the dry season. However, such a service did not exist in Burkina Faso.

Some of the agricultural water resource users $(30 \%)$ who had been supported by a development programme, showed interest in implementing climate smart agriculture resilience strategies. This was, for instance the case with users in the Boulimiougou site participating in the FAO urban agriculture support programme. These observations highlight the need for synergy of adaptation initiatives in long-term planning.

In general, agricultural water resources users faced difficulties in coping with floods whose impacts manifested at plot scale, through submergence of water points, and the destruction of irrigation facilities and crops. Additionally, hydrophobic crop varieties and seedlings are still unavailable. This aspect calls for technical assistance, but above all, for investment in research for flood control at the plot scale. Tailored hydroclimate-based services should then be promoted at gardening locations for the benefit of the poor.

\section{CONCLUSION}

The analysis revealed that Burkina Faso stakeholders involved in agricultural water management were aware of climate impacts on this resource and its implications for food insecurity. At the institutional levels, significant initiatives that can contribute to reduce vulnerability of agricultural water have been taken. This is the case of water management programme and institutions from national to local level. However, these were mostly oriented to drought management. In addition, there is lack of the anticipative vision and absence of integration of climate uncertainties in agriculture water management strategies, and lack of hydrological-based information on agricultural site singularly those concerning gardening activities that take place in the dry season. Furthermore, water resources related policies lacked the way gender issues will be integrated into water resources programme. Besides, there was no clear progress monitoring system like a MRV (Measurement, Reporting, Verification) system for agricultural water sustainability. Concerning farmers in Burkina Faso, for many years, they developed on-site soil and water management techniques (CES/DES) that contribute to facing climate change. The best known of these techniques include planting pits, the Zaî, stone lines", "half-moon". Recently, Crop association and agroforestry were adpoted by farmers.

This informative paper invites policy makers to revise the current water management programme in order to mainstream climate extreme event management in agricultural water resilience strategies. The abovementioned should guide this review (anticipative strategies, climate uncertainties, gender-approach, flood control mechanisms, an AgWater MRV system). However, in the short term, an integrated hydroclimate-based service strategy is needed, singularly in the dry season to face climate impacts in gardening sites. 
Future research should examine the conditions to facilitate the uptake of these options by stakeholders.

\section{ACKNOWLEDGMENT}

This study was funded by the CRES (formerly IAVS) - Centre Africain de Recherche Scientifique et de Formation (https://cresedu.org/). We also thank Burkina Faso stakeholders for having participated in this study.

\section{REFERENCES}

Barbier, B. and Yacouba, Æ.H. 2009. Human Vulnerability to Climate Variability in the Sahel/ : Farmers 'Adaptation Strategies in Northern Burkina Faso. pp. 790-803. https://doi.org/10.1007/s00267-008-92379

Boansi, D., Tambo, J.A. and Müller, M. 2017. Analysis of farmers ' adaptation to weather extremes in West African Sudan Savanna. Weather and Climate Extremes 16:1-13. https://doi.org/10.1016/j.wace. 2017. 03.001

Carter, N., Bryant-Lukosius, D., Dicenso, A., Blythe, J. and Neville, A.J. 2014. The use of triangulation in qualitative research. Oncology Nursing Forum 41(5): 545-547. https://doi.org/10.1188/14.ONF.545-547

Evans, A.E.V., Giordano, M. and Clayton, T. 2012. Investing in agricultural water management to benefit smallholder farmers in Burkina Faso. Country synthesis report. Colombo, Sri Lanka: International Water Management Institute. 22p. https:// hdl.handle.net/10568/34535

Faso, B. and Callo-concha, D. 2018. Farmer perceptions and climate change adaptation in the West Africa Sudan Savannah: Reality Check in. https://doi.org/10.3390/cli60 20044

Filippi, C., Milville, F. and Thiery, D. 1990. Evaluation de la recharge naturelle des aquifères en climat soudano-sahelien par modelisation hydrologique globale: Application a dix sites au burkina faso. Hydrological Sciences Journal, 35(1): 2948. https://doi.org/10.1080/02626669009 492403

Gahi, N., Dongo, K. and Badolo, M. 2015. Using a new approach to design innovative tools for monitoring and evaluating water policy of Burkina Faso in response to climate risks. Climate 3(4):1057-1078. https://doi.org/10.3390/cli3041057

Gahi, N.Z., Dongo, K., Koudou, A. and Badolo, M. 2017. Innovative approach to build a "no regret" framework for reinforcing agricultural water resilience under climate risks and change in Burkina Faso. International Journal of Climate Change Strategies and Management 9(1): 68-86. https://doi.org/10.1108/IJCCSM11-2015-0154

Gahi, N., Macdonald, D., Osbahr, H. and Cornforth, R. 2019. Integrated approach to sustain community livelihoods resilience to hydrometeorological risks in West Africa. African Climate Risks Conference proceeding. pp. 307-312 https:// www.africanclimaterisksconference 2019.org/wp-content/uploads/2019/10/ CONFERENCE-PROCEEDINGS.pdf

Hesse, C., Anderson, S., Cotula, L., Skinner, J. and Toulmin, C. 2013. Managing the boom and bust: Supporting climate resilient livelihoods in the sahel. In: IIED Issue Paper (Issue November). http://pubs.iied. org/11503IIED

Ibrahim, B., Karambiri, H. and Barbe, L. 2014. Changes in rainfall regime over Burkina Faso under the climate change conditions simulated by 5 regional climate models. pp. 1363-1381. https://doi.org/10.1007/ s00382-013-1837-2

Kabore Bontogho, T.N.P.E., Ibrahim, B., Barry, B. and Helmschrot, J. 2015. Intraseasonal variability of climate change in Central Burkina Faso. International Journal of Current Engineering and Technology 
5(3):1955-1965. http://inpressco.com/ category/ijcet

Karambiri, H. and Garc, S.G. 2011. Assessing the impact of climate variability and climate change on runoff in West Africa: The case of Senegal and Nakambe River basins 115: 109-115. https://doi.org/10.1002/asl.317

MEE. 2001. Etat des lieux des ressources en eau du Burkina Faso et de leur cadre de gestion. Rapport version finale, Ministère de l'environnement et de l'eau, Burkina Faso. 243pp. http://www.hubrural.org/ IMG/pdf/burkina_gire_etat_des_lieux.pdf

Mouhouyouddine, A.H., Yameogo, S., Genthon, P., Paturel, J.E. and Guilliod, M. 2017. Groundwater level changes since 1978 in an African City on Basement Rocks: The case of the CIEH Borehole in Ouagadougou (Burkina Faso). Journal of Water Resource and Protection 09(10): 1097-1118. https://doi.org/10.4236/ jwarp.2017.910072

Nagara, G., Lam, W.H., Lee, N.C.H., Othman, F. and Shaaban, M.G. 2015. Comparative SWOT analysis for water solutions in Asia and Africa. Water Resources Management 29(1):125-138. https://doi.org/10.1007/ s11269-014-0831-8

Nana, T.J. 2019. Impact of climate change on cereal production in Burkina Faso. Journal of Agriculture and Environmental Sciences 8(1):14-24. https://doi.org/10.15640/ jaes.v8n1a2

Nyamekye, C., Thiel, M., Schönbrodt-stitt, S., Zoungrana, B.J. and Amekudzi, L.K. 2018. Soil and water conservation in Burkina Faso, West Africa. Sustainability 10(9):124. 3182; https://doi.org/10.3390/su 100 93182

Sanfo, S., Fonta, W.M., Diasso, U.J., Nikiéma, M.P., Lamers, J.P.A. and Tondoh, J.E. 2017. Climate- and environmentinduced intervillage migration in southwestern Burkina Faso, West Africa. Weather, Climate, and Society 9(4):823-
837. https://doi.org/10.1175/WCAS-D-160065.1

Schaeffer, M., Florent, B., Adams, S., De Bruin, K., De Marez, L., Freitas, S., Hof, A., Netherlands and Bill, H. 2013. Africa's Adaptation Gap. Climate-change impacts, adaptation challenges and costs for Africa https://climateanalytics.org/media/ schaeffer_et_al__2013_africao__s_a_ daptation_gap_technical_report.pdf

Schmengler, A.C. 2011. Modeling soil erosion and reservoir sedimentation at hillslope and catchment scale in semi-arid Burkina Faso. 244p. Dissertation, ZEF, Bonn, Germany. https://core.ac.uk/download/pdf/30463 8418.pdf

Sidibe, A. 2005. Farm-level adoption of soil and water conservation techniques in northern Burkina Faso 71: 211-224. https:/ /doi.org/10.1016/j.agwat.2004.09.002

Sossou, S., Babatounde Igue, C. and Diallo, M. 2019. Impact of climate change on cereal yield and production in the Sahel: Case of Burkina Faso. Asian Journal of Agricultural Extension, Economics \& Sociology 37(4):1-11. https://doi.org/ 10.9734/ajaees/2019/v37i430288

Taylor, P., Diello, P., Mahe, G., Paturel, J., Dezetter, A., Delclaux, F., Servat. E. and Ouattara, F. 2009. Relations indices de végétation - Pluie au Burkina Faso: Cas du Bassin Versant du Nakambé. June 2015: 37-41. https://doi.org/10.1623/hysj.50.2. 207.61797

Taylor, P. and Mahe, G.I.L. 2009. Surface / groundwater interactions in the Bani and Nakambe rivers, tributaries of the Niger and Volta basins, West Africa. June 2015: 37-41. https://doi.org/10.1623/hysj.54.4. 704

Zorom, M., Barbier, B., Mertz, O. and Servat, E. 2013. Diversification and adaptation strategies to climate variability: A farm typology for the Sahel. Agricultural Systems 116:7-15. https://doi.org/10.1016/j.agsy. 2012.11.004 